Reprinted with permission from: Weed Science. 1993. 41:441-446.

Published and copyrighted by: Weed Science Society of America. http://www.wssa.net

\title{
Fall cultivation and fertilization to reduce winterhardiness of leafy spurge (Euphorbia esula $)^{1}$
}

\author{
RODNEY G. LYM and CALVIN G. MESSERSMITH \\ Profs., Crop and Weed Sci. Dep., North Dakota State Univ., Fargo, ND 58105
}

\begin{abstract}
:
Reduced-tillage practices have allowed leafy spurge to infest cropland. The reduction in leafy spurge infestation and winterhardiness by fall tillage, $\mathrm{N}$ application, or herbicide treatment was evaluated. Cultivating leafy spurge twice each fall for 3 years provided complete control. Cultivation followed by $\mathrm{N}$ application at $225 \mathrm{~kg} \mathrm{ha}^{-1}$ reduced the stand by $85 \%$ after 3 $\mathrm{yr}$, whereas $\mathrm{N}$ applied alone had little effect. Picloram plus 2,4-D at 0.6 plus $1 \mathrm{~kg} \mathrm{ha}^{-1}$ reduced the infestation to $65 \%$ of the untreated control after 2 years but then the infestation declined rapidly to $1 \%$ after a third application. Leafy spurge cold tolerance decreased as root depth increased. The $\mathrm{GR}_{50}$ and $\mathrm{LT}_{50}$, the temperatures required to reduce total dry weight and survival, respectively, by $50 \%$ varied by root depth and treatment. For example, the $\mathrm{LT}_{50}$ and $\mathrm{GR}_{50}$ for untreated leafy spurge averaged -19 and $<-20^{\circ} \mathrm{C}$ for crowns, respectively, compared to the -16 and $-18^{\circ} \mathrm{C}$ for roots from 0 to $15 \mathrm{~cm}$ deep and -13 and $-12.5^{\circ} \mathrm{C}$ for roots from 15 to $30 \mathrm{~cm}$ deep. The $\mathrm{GR}_{50}$ and $\mathrm{LT}_{50}$ temperature after 2 years of treatment was reduced to $0^{\circ} \mathrm{C}$ by two cultivations in fall or picloram plus 2,4-D. Carbohydrate content was not a good indicator of winterhardiness. Cultivation reduced the leafy spurge root system faster than herbicide treatment especially at the $15-$ to $30-\mathrm{cm}$ depth.
\end{abstract}

\section{Nomenclature:}

Picloram, 4-amino,3,5,6-trichloro-2-pyridinecarboxylic acid; 2,4-D, (2,4dichlorophenoxy)acetic acid; leafy spurge, Euphorbia esula L. $\#^{2}$ EPHES.

\footnotetext{
1 'Received for publication November 23, 1992, and in revised form April 4, 1993. Published with approval of the Director, Agric. Exp. Stn., North Dakota State Univ. as J. Art. No.

${ }^{2}$ Letters following this symbol are a WSSA-approved computer code from Composite List of Weeds, Revised 1989. Available from WSSA, 309 West Clark Street, Champaign, IL 61820.
} 


\section{Additional index words:}

Freeze resistance, perennial, winterkill, carbohydrate, picloram, weed, EPHES.

\section{Introduction}

Leafy spurge is a serious perennial weed problem in range and pasture where it displaces forage species and, if left unchecked, will render pastures unproductive $(14,23)$. Leafy spurge has not been a problem in cropland due to repeated tillage, crop rotation, and the use of herbicides (9). However, as reduced-tillage practices have been adopted, infestations of leafy spurge and other perennial weeds have increased. During a 6-year experiment in North Dakota, perennial weeds did not establish in a conventional-tillage system but appeared within 2 years in both reduced- and no-till systems (27). Once leafy spurge is established in cropland, few options for control are available because the herbicide rates required for control are greater than are labeled for use in cropland (25).

A nonchemical control method is desirable to prevent the rapid establishment of leafy spurge in cropland, especially in limited-tillage areas. Winterkilling may provide natural weed control in conventional-tillage systems because cold injury stresses plants and limits their spread $(21,34)$.

Accumulation of plant sugars is thought to increase winterhardiness by decreasing ice formation and avoiding dehydration, by increasing metabolism of sugars to energy or other protective substances, by directly protecting biomembranes from freezing $(6,29)$, and by decreasing the freezing point of cell sap (21). The sugar content of various tissue in the same plant is commonly proportional to its freezing tolerance.

Disruption of the winterhardening process has increased winterkill in at least one perennial weed species. Fall fertilization and subsequent cultivation reduced the hardiness of quackgrass [Elytrigia repens (L.) Nevski] (12). Rhizomes from fertilized quackgrass plants were killed at $-8 \mathrm{C}$, whereas one-third of the nonfertilized plants survived. A fertilized quackgrass stand, cultivated in the fall, was nearly eliminated the following year. Dexter (11) suggested that the rhizomes were too succulent to winter-harden and thus could not withstand freezing temperatures during winter.

Total nonstructural carbohydrates (TNC), but not total N, decreased in Canada thistle [Cirsium arvense (L.) Scop.] roots following several mowings during the growing season (36). The decreased carbohydrate content was postulated to account for increased winterkill of mowed compared to unmowed Canada thistle plants $(31,36)$.

The direct influence of environmental factors on biochemical changes in perennial weeds during the winterhardening process has received limited study. Perennial weed species undergo seasonal variations in carbohydrate content $(3,4,5)$. Root carbohydrate content of five perennial weed species declined sharply as growth began in the spring and reached a minimum level just prior to seed maturation $(1,2)$. The low carbohydrate con- 
tent generally persisted until rapid storage of carbohydrates began during cool fall weather and continued until topgrowth was killed by freezing temperatures.

Water-soluble carbohydrate (mostly sucrose) content of leafy spurge roots generally increased and starch content decreased beginning in mid-August until soil freeze-up (7, 24). Accumulation of sucrose and hydrolysis of starch are the first stages of hardening in herbaceous plants $(15,20)$. Decreasing temperatures have induced starch degradation in roots of common mullein (Verbascum thapsus L.), a biennial weed (16). Disruption of this process in leafy spurge may increase winter-induced injury and thus make the plant more susceptible to control practices.

The objective of this research was to determine the influence of fall tillage and $\mathrm{N}$ fertilization on leafy spurge winterhardiness and survival. Late-season tillage and/or fertilization could be added to present farming practices for perennial weed control without disrupting a cropping sequence.

\section{Materials and methods}

Effect of late-season $\mathrm{N}$ use, cultivation (twice), cultivation plus $\mathrm{N}$, or herbicide treatments on winterhardiness of leafy spurge was evaluated. Decline in winterhardiness was measured as changes in vigor and the lethal temperature required for winterkill, changes in root carbohydrate content, and reduction of plant population. The plots were 3 by 12 $\mathrm{m}$, and each treatment was replicated three times in a split plot in time model in a randomized complete block design. The experiment was established in 1989 on unused farmland near Chaffee, ND.

The site had approximately $80 \%$ ground cover $\left(110\right.$ stems $\left.\mathrm{m}^{-2}\right)$ of leafy spurge, no history of herbicide application, and had not been farmed for over 20 years. The soil was a Fairdale loam (fine-loamy, mixed, frigid Mollic Udifluvents) with 3.8\% organic matter and a $\mathrm{pH}$ of 7.8. Soil fertility averaged 12,16 , and $940 \mathrm{~kg} \mathrm{ha}^{-1} \mathrm{~N}, \mathrm{P}$, and $\mathrm{K}$, respectively. Grass weeds were controlled with fluazifop $\{( \pm)-2-[4-[[5-($ trifluoromethyl)-2-pyridinyl] oxy]phenoxy]propanoic acid $\}$ applied at $0.22 \mathrm{~kg} \mathrm{ha}^{-1}$ May 25 and again July 10, 1989 prior to initiation of fall treatments.

The initial cultivation was conducted August 15, 1989, which was after leafy spurge had initiated fall regrowth. The soil was cultivated to a $15-\mathrm{cm}$ depth using a field cultivator with 18-cm-wide shovel sweeps. There were four passes (forward and back) during the initial cultivation in 1989. Plant material on the soil surface was removed from the plots the first year after the second pass because trash interfered with cultivation. $\mathrm{N}(40-0-0 \mathrm{~N}: \mathrm{P}: \mathrm{K})$ at $225 \mathrm{~kg} \mathrm{ha}^{-1}$ was surface applied by hand to the fertilizer only and cultivation followed by fertilizer treatments. The herbicide treatment and second cultivation were conducted September 13, 1989. Leafy spurge regrowth was approximately 10 to $15 \mathrm{~cm}$ tall before the second cultivation and four passes (forward and back) were again made with the cultivator. Herbicides were applied using a tractor-mounted sprayer delivering $47 \mathrm{~L} \mathrm{ha}^{-1}$ water at $240 \mathrm{kPa}$ with 8001 flat-fan nozzles ${ }^{3}$. All treatments were repeated

${ }^{3}$ Spraying Systems Co., North Ave., Wheaton, IL 60188.

Page 3 of 11 
on approximately the same dates in 1990 and 1991, except there were two rather than four passes in the cultivation plots.

Roots of leafy spurge were collected from each treatment approximately November 1 of each year after the soil temperature was $4.4^{\circ} \mathrm{C}$ or lower. Plant material was collected from the 0 - to 15 - and $15-$ to $30-\mathrm{cm}$ depths, placed in coolers with ice for transport, and then placed in moist peat and stored at $2^{\circ} \mathrm{C}$.

Plant material from each plot was divided into root crowns and root segments $10 \mathrm{~cm}$ long of uniform diameter within 7 days after harvest. Crown and root samples were divided and used for the artificial freezing experiments or for carbohydrate analysis. Samples for carbohydrate analyses were washed and frozen.

Stand density was evaluated at the beginning of the experiment and in June of each subsequent year. Leafy spurge stems were counted in four $0.25-\mathrm{m}^{2}$ quadrats per plot at approximately the same location each year.

\section{Cold hardiness}

The artificial freezing experiment was a randomized complete block design as in the field with five crowns and six root pieces per pot. Plant material was placed between layers of soil (500 g total), collected from the experiment site, in round plastic pots $15 \mathrm{~cm}$ in diameter by $12 \mathrm{~cm}$ deep. Soil moisture was raised to $50 \%$ of field capacity (gravimetric water content at $-0.03 \mathrm{MPa}$ ) to prevent supercooling of water within the plant material which was stored in a domestic freezer with modified temperature control (35) at $0^{\circ} \mathrm{C}$ for 24 hours to reach temperature equilibrium. Thermocouples of copper-constantan were placed in the soil of selected pots to monitor temperature.

Plant material was frozen to temperatures of $0,-4,-8,-12,-16$, or $-20 \mathrm{C}$. The temperature was lowered at a rate of $1^{\circ} \mathrm{C} \mathrm{h}^{-1}$ until the $-4^{\circ} \mathrm{C}$ minimum temperature was reached and then was maintained at that point for $20 \mathrm{~h}$. Plant material brought to colder temperatures was maintained below $0^{\circ} \mathrm{C}$ longer than that removed at a warmer temperature. For example, material removed after 20 hours at $-4^{\circ} \mathrm{C}$ was frozen 48 hours after reaching $0^{\circ} \mathrm{C}\left(24\right.$ hours at $0^{\circ} \mathrm{C}, 4$ hours to reach $-4 \mathrm{C}$, and 20 hours at $\left.-4^{\circ} \mathrm{C}\right)$, while material removed at $-8^{\circ} \mathrm{C}$ had been frozen 72 hours $\left(48\right.$ hours to reach $-4^{\circ} \mathrm{C}, 4$ hours to reach $-8^{\circ} \mathrm{C}$, and 20 hours at $-8^{\circ} \mathrm{C}$ ). This procedure simulated field conditions in North Dakota where soil temperatures drop slowly and temperatures are coldest in mid-January or 66 days after the soil first reaches $0^{\circ} \mathrm{C}^{4}$. Pots with $500 \mathrm{~g}$ of moist soil replaced those removed at each temperature and all pots in the freezer were rerandomized daily, then the cycle was repeated to reach the next colder temperature.

After the desired temperature regime was completed, pots were removed from the fteezer, placed in containers of crushed ice, and allowed to thaw at 1 to $2^{\circ} \mathrm{C}$ for a slow warmup period. It took 72 to 96 hours for the plant material to reach $1^{\circ} \mathrm{C}$. Plant sections maintained in pots of soil at $1^{\circ} \mathrm{C}$ during the freezing experiment were used as untreated controls. Each frozen soil temperature had its own check, so plant material held in the

\footnotetext{
${ }^{4}$ Personal communication, North Dakota State Univ. Soil Sci. Dep., Farr, ND 58105.
} 
freezer was compared to material held at $1^{\circ} \mathrm{C}$ for an equal time period to determine the temperatures required to reduce total dry weight $\left(\mathrm{GR}_{50}\right)^{5}$ and percent survival (lethal temperature) $\left(\mathrm{LT}_{50}\right)^{5}$ by $50 \%$, respectively.

After thawing, plant sections were treated with benomyl [methyl- 1 (butylcarbamoyl)-2-benzimidazolecarbamate], placed in pots containing peat, and fertilized with a water soluble fertilizer equivalent to $100: 50: 100 \mathrm{~kg} \mathrm{ha}^{-1} \mathrm{~N}: \mathrm{P}: \mathrm{K}$. The plants were grown for 16 and 28 days for crowns and roots, respectively, because shoots took longer to emerge from roots than from crowns. Plants were grown at $30 / 25^{\circ} \mathrm{C}$ day/night temperature with a 16-hour photoperiod, which are optimum growing conditions for leafy spurge in the greenhouse (22). New shoot growth was removed, counted, oven dried, and weighed. No shoot emergence or growth indicated plant death. A reduction in dry weight of shoots produced from surviving tissue compared to the check plants was considered an indication of reduction in vigor from freezing temperatures apart from direct cell death. Root material was washed and frozen for later carbohydrate analyses.

\section{Carbohydrate analyses}

Plant material for carbohydrate analyses was washed and frozen and then dried at $60^{\circ} \mathrm{C}$. Crown and root sections were ground in a wiley mill (No. 10 mesh) and weighed. Water-soluble carbohydrates from 250-mg samples were extracted with $50 \mathrm{ml}$ water at $27^{\circ} \mathrm{C}$ for 1 hour. Samples were filtered and residue was saved for insoluble carbohydrate determination. The water extract was diluted to $100 \mathrm{ml}$, and a 1.5 -ml aliquot was centrifuged for 3 minutes at a relative centrifugal force of $17200 \times g$ to precipitate proteins. Water-soluble carbohydrates were determined colorimetrically by adding $1 \mathrm{ml}$ of $20 \%$ by vol phenol and $5 \mathrm{ml}$ concentrated sulfuric acid to a $0.1-\mathrm{ml}$ aliquot of extract and incubating 20 minutes at $27^{\circ} \mathrm{C}$ as described by Dubois et al. (13).

Insoluble carbohydrates were extracted by placing the residue in $15 \mathrm{ml}$ distilled water and boiling for 5 minutes followed by adding $10 \mathrm{ml} 0.5 \%$ amyloglucosidase buffered to $\mathrm{pH} 4.9$, and incubating at $38^{\circ} \mathrm{C}$ for 36 hours (32). Insoluble carbohydrates were determined colorimetrically as previously described. Three subsamples per plot were analyzed, and results are presented as milligrams carbohydrate per gram root dry weight.

Carbohydrate analyses of root material first grown in the greenhouse to determine $\mathrm{LT}_{50}$ and $\mathrm{GR}_{50}$ were conducted similarly. However, due to the small amount of material available and the low concentration of carbohydrates, the water extract was diluted in only $50 \mathrm{ml}$ of water. Root or crown material that did not produce shoots was not analyzed.

\footnotetext{
${ }^{5}$ Abbreviations: $\mathrm{GR}_{50}$, temperature required to reduce total dry weight by $50 \%$; $\mathrm{LT}_{50}$, temperature required to reduce survival by $50 \%$.
} 


\section{Data analyses}

Analyses of variance were used to test for significance with a protected F-test. Transformation of percent data to arc sine square root did not change interpretation of results. Therefore, untransformed data are presented. The $\mathrm{LT}_{50}$ and $\mathrm{GR}_{50}$ were calculated from only the most linear portion of the curves; i.e., temperature means that were outside the linear portion of the curve (i.e., uninjured and dead plants) were removed from the regression analysis.

\section{Results and discussion}

Cultivating twice each fall for 3 years completely controlled leafy spurge and reduced the infestation more rapidly than one cultivation plus $\mathrm{N}$ or $\mathrm{N}$ alone (Table 1). Leafy spurge shoot density initially increased following the first year of cultivation (1990) to $190 \%$ of the untreated control which is a common occurrence when leafy spurge is disrupted by cultivation for the first time $(9,10)$. However, shoot density declined rapidly to 30 and $0 \%$ in 1991 and 1992, respectively. Cultivation plus $\mathrm{N}$ treatment reduced the stand to only $80 \%$ of the untreated control after 2 years but the infestation declined, to $15 \%$ after 3 years. Picloram plus 2,4-D at 0.6 plus $1 \mathrm{~kg} \mathrm{ha}^{-1}$ reduced the infestation to only $65 \%$ of the untreated control after two treatments but the infestation declined rapidly to $1 \%$ following the third application.

Cultivation conducted every 14 to 20 days throughout the growing season has effectively controlled leafy spurge $(9,10,17)$, sometimes up to $90 \%$ in 1 year $(10)$. Fall cultivation alone in this study reduced the leafy spurge infestation with fewer operations than required using early- or midseason cultivation, but it took 2 to 3 years to reduce the infestation by $80 \%$ or better. Picloram plus $2,4-\mathrm{D}$ also reduced the infestation but not as rapidly as two cultivations. Derscheid et al. (10) found the combination of herbicide plus cultivation was more effective than either treatment alone in reducing a leafy spurge infestation. However, picloram application may not be practical if a broadleaf crop susceptible to picloram residues is part of a cropping rotation, unless application is made prior to a fallow period.

$\mathrm{N}$ alone probably will not reduce a leafy spurge infestation. $\mathrm{N}$ alone initially increased leafy spurge density to $140 \%$ of the untreated control but the infestation then gradually declined to $75 \%$ by the third year (Table 1). Fall fertilization alone also did not reduce a leafy spurge stand in Nebraska, but herbicides applied the following spring were more effective on fall-fertilized compared to nonfertilized leafy spurge (28). $\mathrm{N}$ also increased spotted knapweed (Centaurea maculosa Lamarck) and Canada thistle stands in Montana $(19,33)$, but no subsequent decrease in stand density was reported as with quackgrass (12).

Root cold hardiness and carbohydrate content. Leafy spurge cold tolerance decreased as root depth increased (Table 2). Leafy spurge crowns were most cold tolerant followed by root tissue from 0 to $15 \mathrm{~cm}$ deep and then roots from 15 to $30 \mathrm{~cm}$. deep. The $\mathrm{GR}_{50}$ and $\mathrm{LT}_{50}$ for untreated leafy spurge averaged over years was -19 and $<-20^{\circ} \mathrm{C}$ (colder than $-20^{\circ} \mathrm{C}$ for crowns, respectively, compared to -16 and $-18^{\circ} \mathrm{C}$ for roots from the 0 - to $15-\mathrm{cm}$. depth and -13 and $-12.5^{\circ} \mathrm{C}$ for roots from 15 to $30 \mathrm{~cm}$. deep. These $\mathrm{GR}_{50}$ 
and $\mathrm{LT}_{50}$ data are similar to those from leafy spurge roots growing in a pastureland environment (30).

Table 1. Leafy spurge control with fall-applied $\mathbf{N}$ and/or cultivation or a herbicide treatment for 3 years beginning in $1989^{a}$.

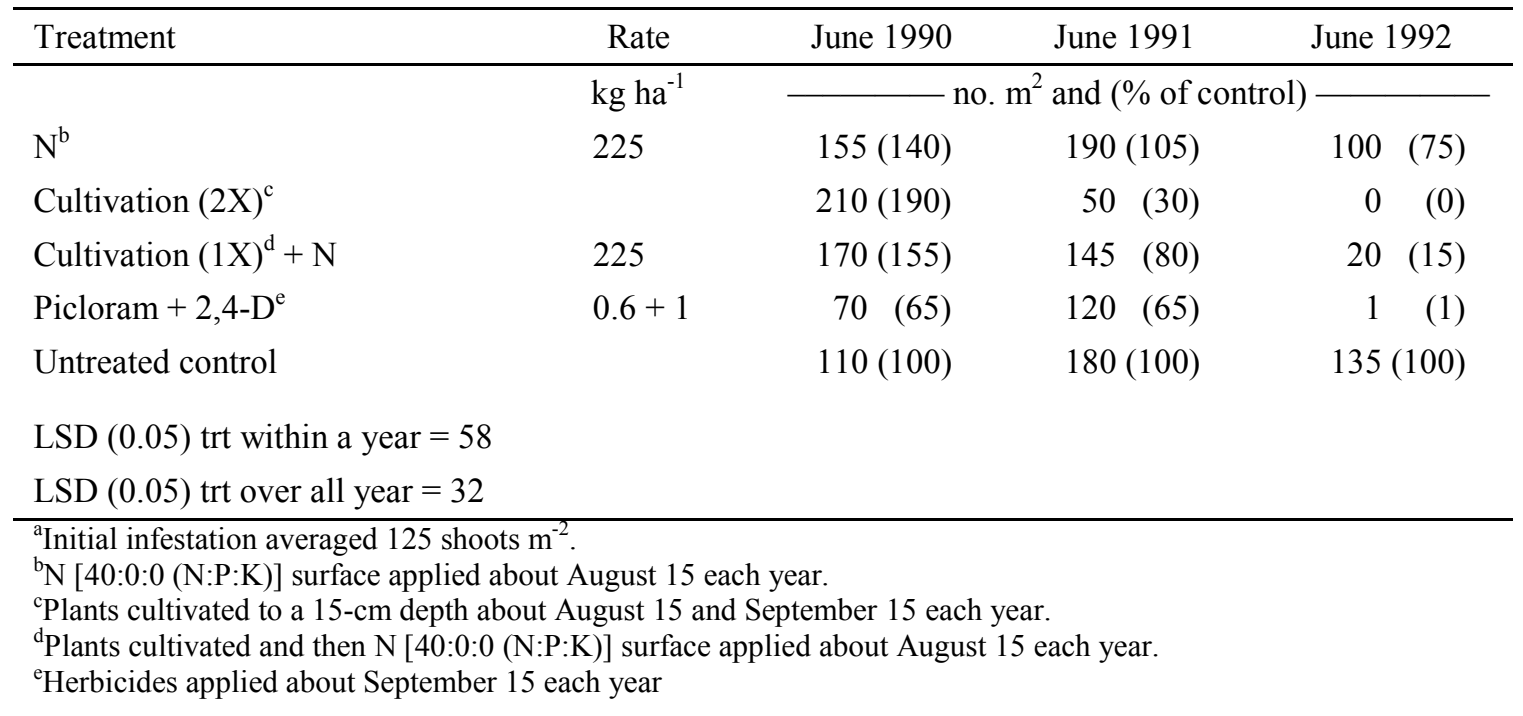

The $\mathrm{GR}_{50}$ and $\mathrm{LT}_{50}$ of leafy spurge roots from 15 to $30 \mathrm{~cm}$ deep following the second year of treatment were reduced to $0^{\circ} \mathrm{C}$ by two fall cultivations or picloram. plus 2,4-D at 0.6 plus $1 \mathrm{~kg} \mathrm{ha}^{-1}$ (Table 2). Fall-applied $\mathrm{N}$ reduced both the $\mathrm{GR}_{50}$ and $\mathrm{LT}_{50}$ of roots from both depths evaluated but did not reduce the $\mathrm{GR}_{50}$ and $\mathrm{LT}_{50}$ of crown tissue. Cultivation plus $\mathrm{N}$ reduced cold hardiness of leafy spurge roots more than $\mathrm{N}$ alone but not as much as two cultivations alone.

Carbohydrate content of leafy spurge crowns and roots generally did not decrease when stand density and cold hardiness declined, until the infestation was reduced to near $0 \%$ (Table 3). The two most effective treatments for reducing leafy spurge infestation and cold tolerance, i.e. two cultivations or picloram plus 2,4-D, only slightly decreased root carbohydrate content, and most of this decrease occurred after the third treatment. Perhaps root tissues need a critical concentration of carbohydrate reserves to remain viable. Virtually all treatments with stem emergence in 1992 (Table 1) had $240 \mathrm{mg} \mathrm{g}^{-1}$ or more total carbohydrate (water-soluble and -insoluble) content (Table 3). The only exception was root tissue (15- to 30-cm depth in 1992) from plants treated with picloram plus 2,4-D which had $60 \mathrm{mg} \mathrm{g}^{-1}$ total carbohydrate content (Table 3). However, emerged leafy spurge shoots from this treatment were not vigorous.

Cultivation tended to reduce both the water-soluble and water-insoluble carbohydrate content of roots below the depth of cultivation (15 to $30 \mathrm{~cm}$ deep) more rapidly than picloram plus 2,4-D (Table 3). This implies that cultivation was more stressful to the leafy spurge root system than herbicide treatment and required plants to use more energy reserves to regrow. When picloram was absorbed by leafy spurge shoots, most of the picloram translocated to the root zone was exuded from the crown region of the plant (18) and 
did not injure the roots below. Thus, tillage $15 \mathrm{~cm}$ deep probably destroyed more of the root system and weakened the plant more than the herbicide treatment. $\mathrm{N}$ alone did not or only slightly reduced the carbohydrate content of leafy spurge crown and root tissues. With N plus cultivation, the carbohydrate content was or tended to be greater than when the plants were only fertilized. Crown and root tissue from plants first grown in the greenhouse for $\mathrm{GR}_{50}$ and $\mathrm{LT}_{50}$ determination averaged less than $50 \mathrm{mg} \mathrm{g}^{-1}$ of watersoluble and $10 \mathrm{mg} \mathrm{g}^{-1}$ of water-insoluble carbohydrates in the roots regardless of treatment (data not shown). Thus, the root system depleted nearly all carbohydrate reserves to regrow and a follow-up cultivation and/or herbicide treatment 2 to 4 weeks after shoot emergence probably would eliminate all roots at least to the $30-\mathrm{cm}$ depth sampled in these experiments.

Table 2. GR $_{50}$ and $L T_{50}$ temperatures for leafy spurge crowns and root tissue from two depths as affected by fall-applied $\mathrm{N}$ and/or cultivation, or herbicide treatment ${ }^{\mathrm{a}}$.

\begin{tabular}{|c|c|c|c|c|c|c|c|c|c|c|}
\hline \multirow[b]{3}{*}{ Treatment } & \multirow[b]{3}{*}{ Rate } & \multicolumn{9}{|c|}{$\mathrm{GR}_{50}$ and $\mathrm{LT}_{50}$ temperatures by plant part } \\
\hline & & \multicolumn{3}{|c|}{ Crown } & \multicolumn{3}{|c|}{$\operatorname{Root}(0-15 \mathrm{~cm})$} & \multicolumn{3}{|c|}{ Root $(15-30 \mathrm{~cm})$} \\
\hline & & 1989 & 1990 & 1991 & 1989 & 1990 & 1991 & 1989 & 1990 & 1991 \\
\hline & $\mathrm{kg} \mathrm{ha}^{-1}$ & & 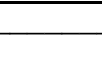 & 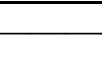 & $\mathrm{GR}_{50}$ & mperat & re $(\mathrm{C})$ & & & \\
\hline $\mathrm{N}^{\mathrm{b}}$ & 225 & -20 & $<-20$ & -19 & -18 & -12 & $>0$ & -15.5 & 12.5 & $>0$ \\
\hline Cultivation $(2 X)^{c}$ & & NM & NM & NM & NM & NM & NM & -17.5 & $>0$ & NM \\
\hline Cultivation $(1 X)^{d}+N$ & 225 & NM & NM & NM & NM & NM & NM & -12 & -7 & NM \\
\hline Pictoram $+2,4-\mathrm{D}^{\mathrm{e}}$ & $0.6+1$ & $<-20$ & $>0$ & NM & -14 & $>0$ & NM & -14.5 & $>0$ & NM \\
\hline \multirow[t]{2}{*}{ Untreated control } & & -18 & $<-20$ & -18 & -20 & -16.5 & -13 & -17.5 & -11 & -10.5 \\
\hline & & \multicolumn{9}{|c|}{$-\mathrm{LT}_{50}$ temperature $(\mathrm{C})$} \\
\hline $\mathrm{N}^{\mathrm{b}}$ & 225 & $<-20$ & $<-20$ & $<-20$ & -20 & -15.5 & -1.5 & -15.5 & -11.5 & -10.5 \\
\hline Cultivation $(2 X)^{c}$ & & NM & NM & NM & NM & NM & NM & -14.5 & $>0$ & NM \\
\hline Cultivation $(1 \mathrm{X})^{\mathrm{d}}+\mathrm{N}$ & 225 & NM & NM & NM & NM & NM & NM & -12.5 & -3.5 & NM \\
\hline Picloram $+2,4-\mathrm{D}^{\mathrm{e}}$ & $0.6+1$ & $<-20$ & $>0$ & NM & -15.4 & 0 & NM & -14.5 & $>0$ & $\mathrm{NM}$ \\
\hline Untreated control & & $<-20$ & $<-20$ & $<-20$ & -18 & -17.5 & -19 & -14.5 & -10 & -13.5 \\
\hline \multicolumn{11}{|c|}{$\begin{array}{l}\text { The linear regression equation for the most linear portion of the curve was used to calculat } \\
\text { tures; i.e., temperatures required to reduce total dry weight and survival by } 50 \% \text {. Temperat } \\
\text { than }-20^{\circ} \mathrm{C} \text { and }>0 \text { means less than } 50 \% \text { of the plant roots grew at } 0 \mathrm{C} \text {. The standard error } \\
\text { all values. NM }=\text { not measured because too little root material remained for evaluation. } \\
\text { b } \mathrm{N} \text { [ } 40: 0: 0(\mathrm{~N}: \mathrm{P}: \mathrm{K})] \text { surface applied about August } 15 \text { each year. } \\
{ }^{\mathrm{c}} \text { Plants cultivated to a } 15-\mathrm{cm} \text { depth about August } 15 \text { and September } 15 \text { each year. } \\
\text { d Plants cultivated and then } \mathrm{N} \text { [40:0:0 (N:P:K)] surface applied about August } 15 \text { each year. } \\
{ }^{\text {e }} \text { Herbicides applied about September } 15 \text { each year. }\end{array}$} \\
\hline
\end{tabular}

Cultivation and herbicide treatments reduced leafy spurge cold tolerance and infestation more than $\mathrm{N}$; however, root carbohydrate reserves were not a good indicator of the decline in cold tolerance. Cyr and Bewley $(7,8)$ have suggested that nitrogenous compounds are more important than storage carbohydrates in the ability of leafy spurge to overwinter. Also, picloram translocation to leafy spurge roots did not increase with carbohydrate translocation in the fall (26). Thus, the role of storage carbohydrates in peren- 
nial weed control probably has been overemphasized. Carbohydrates may not be the key plant constituent to predict cold hardiness or herbicide translocation.

Cultivation alone or combined with a herbicide treatment in the fall will control leafy spurge in cropland. The cultivation need not be intensive over one or more growing seasons as previously recommended $(9,10)$. The fall cultivation program is advantageous because it allows crops to be grown during the season and limits soil exposure to erosion. It will take longer to control an infestation if a single cultivation is used instead of two per season but that may be a more practical management option when the soil is subject to erosion or minimal tillage is desired.

Table 3. Carbohydrate content for leafy spurge crowns and for root tissue at two depths as affected by fall-applied $\mathrm{N}$ and/or cultivation or herbicide treatment ${ }^{\mathrm{a}}$.

\begin{tabular}{|c|c|c|c|c|c|c|c|}
\hline \multirow{3}{*}{$\begin{array}{l}\text { Root section } \\
\text { and treatment }\end{array}$} & \multirow[b]{3}{*}{ Rate } & \multicolumn{6}{|c|}{ Carbohydrate by fraction } \\
\hline & & \multicolumn{3}{|c|}{ Water-soluble } & \multicolumn{3}{|c|}{ Water-insoluble } \\
\hline & & 1989 & 1990 & 1991 & 1989 & 1990 & 1991 \\
\hline & $\mathrm{kg} / \mathrm{ha}^{-1}$ & 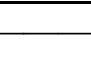 & 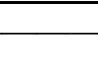 & $r$ & & & \\
\hline \multicolumn{8}{|l|}{ Crown: } \\
\hline $\mathrm{N}^{\mathrm{b}}$ & 225 & 140 & 150 & 170 & 50 & 100 & 70 \\
\hline Cultivation $(2 X)^{c}$ & & NM & NM & NM & NM & NM & NM \\
\hline Cultivation $(1 X)^{d}+N$ & 225 & NM & NM & NM & NM & NM & NM \\
\hline Picloram + 2,4-D $\mathrm{D}^{\mathrm{e}}$ & $0.6+1$ & 100 & 120 & NM & 40 & 90 & NM \\
\hline Untreated control & & 180 & 160 & 180 & 70 & 120 & 80 \\
\hline $\operatorname{LSD}(0.05)$ & & 16 & 35 & NS & 13 & 10 & NS \\
\hline \multicolumn{8}{|l|}{$\operatorname{Root}(0-15 \mathrm{~cm})$ : } \\
\hline $\mathrm{N}^{\mathrm{b}}$ & 225 & 170 & 120 & 160 & 70 & 150 & 80 \\
\hline Cultivation $(2 X)^{c}$ & & NM & NM & NM & NM & NM & NM \\
\hline Cultivation $(1 \mathrm{X})^{\mathrm{d}}+\mathrm{N}$ & 225 & NM & NM & NM & NM & NM & NM \\
\hline Picloram + 2,4-D ${ }^{\mathrm{e}}$ & $0.6+1$ & 180 & 130 & NM & 60 & 120 & NM \\
\hline Untreated control & & 160 & 180 & 200 & 70 & 180 & 90 \\
\hline $\operatorname{LSD}(0.05)$ & & 20 & NS & 35 & NS & NS & NS \\
\hline \multicolumn{8}{|l|}{ Root $(15-30 \mathrm{~cm})$ : } \\
\hline $\mathrm{N}^{\mathrm{b}}$ & 225 & 140 & 130 & 140 & 110 & 150 & 100 \\
\hline Cultivation $(2 X)^{\mathrm{c}}$ & & 210 & 100 & NM & 120 & 90 & NM \\
\hline Cultivation $(1 \mathrm{X})^{\mathrm{d}}+\mathrm{N}$ & 225 & 170 & 150 & 150 & 110 & 240 & 250 \\
\hline Picloram + 2,4-D $\mathrm{D}^{\mathrm{e}}$ & $0.6+1$ & 180 & 110 & 40 & 120 & 140 & 20 \\
\hline Untreated control & & 180 & 160 & 180 & 120 & 200 & 180 \\
\hline $\operatorname{LSD}(0.05)$ & & 26 & 30 & 26 & NS & 71 & 83 \\
\hline 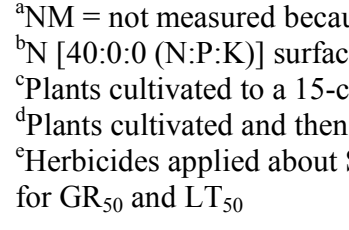 & $\begin{array}{l}\text { se too littl } \\
\text { e applied a a } \\
\text { m depth ab } \\
\text { N [ } 40: 0: 0\end{array}$ & ugust & $\begin{array}{l}\text { ained } \\
\text { h year } \\
\text { Septe } \\
\text { oplied }\end{array}$ & $\begin{array}{l}\text { eacl } \\
\text { lugus }\end{array}$ & $\begin{array}{l}\text { h year } \\
\text { ts first }\end{array}$ & & ouse \\
\hline
\end{tabular}




\section{Literature cited}

1. Agbakoba, C.S.O. and J. R. Goodin. 1969. Effects of stage of growth of field bindweed on absorption and translocation of ${ }^{14} \mathrm{C}$-labeled 2,4-D and picloram. Weed Sci. 17:436-438.

2. Amy, A. C. 1932. Variations in the organic reserves in underground parts of five perennial weeds from late April to November. Minn. Agric. Exp. Stn. Tech. Bull. 84.

3. Bakke, A. L., W. G. Gaessler, and W. E. Loomis. 1939. Relation of root reserve to control of European bindweed. Pages 114-144 in Iowa Agric. Exp. Stn. Res. Bull. 254.

4. Barr, C. G. 1940. Organic reserves in the roots of field bindweed. J. Agric. Res. 60:391-414.

5. Barr, C. G. 1942. Reserve foods in the roots of whiteweed (Cardaria draba var. repens). J. Agric. Res. 64:725-740.

6. Chen, H. and P. H. Li. 1980. Biochemical changes in tuber-bearing Solanum species in relation to frost hardiness during cold acclimation. Plant Physiol. 66:414-421.

7. Cyr, D. R. and J. D. Bewley. 1989. Carbon and nitrogen reserves of leafy spurge (Euphorbia esula) roots as related to overwintering strategy. Physiol. Plant. 77:67-72.

8. Cyr, D. R. and J. D. Bewley. 1990. Seasonal variation in nitrogen storage reserves in the roots of leafy spurge (Euphorbia esula) and response to decapitation and defoliation. Physiol. Plant. 78:361-366.

9. Derscheid, L. A., K. Wallace, and R. L. Nash. 1960. Leafy spurge control with cultivation, cropping and chemicals. Weeds 8:115-127.

10. Derscheid, L. A., G. A. Wicks, and W. H. Wallace. 1963. Cropping, cultivation, and herbicides to eliminate leafy spurge and prevent reinfestation. Weeds 11:105-111.

11. Dexter, S. T. 1937. The winter hardiness of weeds. J. Am. Soc. Agron. 29:507-528.

12. Dexter, S. T. 1956. The evaluation of crop plants for winter hardiness. Adv. Agron. 8:203-239.

13. Dubois, M. K., K. A. Gilles, J. K. Hamilton, P. A. Rebers, and F. Smith. 1956. Colorimetric method for determination of sugars and related substances. Anal. Chem. 28:350-356.

14. Dunn, P. H. 1979. The distribution of leafy spurge (Euphorbia esula) and other weedy spurges in the United States. Weed Sci. 27:509-516.

15. Frazier, J. C. 1943. Amount, distribution and seasonal trend of certain organic reserves in the root system of field bindweed. Plant Physiol. 18: 167-184.

16. Gleir, J. H. and J. L. Caruso. 1973. Low-temperature induction of starch degradation in roots of a biennial weed. Cryobiology 10: 328-330.

17. Hanson, H. C. and V. E. Rudd. 1933. Leafy spurge life history and habits. North Dakota Agric. Exp. Sm. Bull. 249.

18. Hickman, M. V., C. G. Messersmith, and R. G. Lym. 1989. Picloram release from leafy spurge (Euphorbia esula) roots in the field. Weed Sci. 37:167-174.

19. Hodgson, J. M. 1968. The nature, ecology, and control of Canada thistle. U.S. Dep. Agric. Tech. Bull. 1386.

20. Kacpersku-Palacz, A. 1978. Mechanism of cold acclimation in herbaceous plants. Pages 139-152 in P. H. Li and A. Saki, eds. Plant Cold Hardiness and Freezing Stress. Academic Press, New York.

21. Levitt, J. 1980. Responses of plants to environmental stresses. Vol. 1. Chilling, Freezing, and High Temperature Stresses. Academic Press, New York.

22. Lym, R. G. 1992. Propagation of Euphorbia esula for leafy spurge biocontrol agents. Weed Sci. 40:326-332. 
23. Lym, R. G. and D. R. Kirby. 1987. Cattle foraging behavior in leafy spurge (Euphorbia esula)-infested rangeland. Weed Technol. 1: 314-318.

24. Lym, R. G. and C. G. Messersmith. 1987. Carbohydrates in leafy spurge roots as influenced by environment. J. Range Manage. 40:139-144.

25. Lym, R. G. and C. G. Messersmith. 1990. Cost-effective long-term leafy spurge (Euphorbia esula) control with herbicides. Weed Technol. 4:635-641.

26. Lym, R. G. and C. G. Messersmith. 1991. Correlation of environment and root carbohydrate content to picloram translocation in leafy spurge. J. Range Manage. 44:254-258.

27. Miller, S. D. and J. D. Nalewaja. 1985. Weed spectrum change and control in reduced-till wheat. North Dakota Farm Res. 43(1):11-14.

28. Regimbal, G. A. and A. R. Martin. 1985. The influence of growth regulators and nitrogen on leafy spurge (Euphorbia esula) control with picloram. Weed Sci. 33:109-113.

29. Saki, A. and W. Larcher. 1987. Frost Survival of Plants, Responses and Adaptation to Freezing Stress. Springer-Verlag, New York.

30. Schimming, W. K. and C. G. Messersmith. 1988. Freezing resistance of overwintering buds for four perennial weeds. Weed Sci. 36:568-573.

31. Seely, C. I. 1952. Controlling perennial weeds with tillage. Idaho Agric. Exp. Stn. Bull. 288.

32. Smith, D. 1981. Removing and analyzing total nonstructural carbohydrates from plant tissue. Univ. Wisconsin Res. Rep. No. 2107.

33. Story, J. M., K. W. Boggs, and D. R. Grahm. 1989. Effects of nitrogen fertilization on spotted knapweed and competing vegetation in western Montana. J. Range Manage. 42:222-225.

34. Sutcliffe, J. F. 1977. Plants and Temperature. Camelot Press, Ltd., Southampton, England.

35. Voisey, P. W. and F. Moulton. 1968. Precise temperature control for a domestic freezer. Can. J. Plant Sci. 49:107-110.

36. Welton, F. A., V. H. Morris, and A. J. Hartzler. 1929. Organic food reserves in relation to the eradication of Canada thistles. Ohio Agric. Exp. Stn. Bull. 441. 